\title{
DIR/FLOORTIME UNTUK MENINGKATKAN KOMUNIKASI ANTARA ANAK DENGAN AUTISME DAN IBU DENGAN PROFIL SENSORI BERBEDA
}

\author{
Ezra Dessabela Isnannisa, Lia Mawarsari Boediman \\ Fakultas Psikologi, Universitas Indonesia \\ Jl. Margonda Raya, Pondok Cina, Kecamatan Beji, Kota Depok, Jawa Barat 16424 \\ Email: ezradessabela@gmail.com; lboediman72@gmail.com
}

\begin{abstract}
ABSTRAK. Kesulitan menjalin komunikasi adalah salah satu fitur utama pada Autism Spectrum Disorder (ASD). Anak dengan ASD cenderung memiliki gangguan pemrosesan sensori yang berdampak pada defisit kemampuan komunikasi. Hal tersebut membuat anak membutuhkan bantuan pengasuh untuk meregulasi diri sebelum dapat menjalin komunikasi dengan orang lain. Salah satu intervensi yang membantu meningkatkan kemampuan komunikasi adalah Developmental, Individual Differences, Relationship (DIR)/Floortime. Intervensi ini mempertimbangkan keunikan profil sensori dan perkembangan functional emotional partisipan sebagai landasan pembuatan program, serta melibatkan pengasuh secara aktif. Secara lebih lanjut, penelitian ini bertujuan untuk mengevaluasi efektivitas DIR/Floortime untuk meningkatkan komunikasi antar anak usia 4 tahun 2 bulan dengan autisme dan ibu dengan profil sensori yang berbeda. Penelitian ini menggunakan single case design dan multiple baselines across situations untuk mengevaluasi penerapan DIR/ Floortime pada situasi free dan semi-structured play. Lembar Observasi Circle of Communication $(\mathrm{CoC})$ digunakan untuk menghitung jumlah komunikasi dua arah yang terjalin antara anak dan ibu. Skor kapasitas perkembangan functional emotional anak dan ibu juga diukur menggunakan Functional Emotional Assesment Scale untuk mengetahui kapasitas perkembangan yang melandasi kemampuan komunikasi. Hasil penelitian mengindikasikan bahwa DIR/Floortime efektif untuk meningkatkan jumlah dan kualitas komunikasi antara anak dan ibu. Setelah intervensi, anak lebih sering melakukan kontak mata, melakukan inisiasi dan respons verbal, serta tampak lebih engaged dalam berinteraksi bersama ibu. Keterlibatan aktif ibu dalam intervensi membuat ibu langsung merasakan perubahan positif pada anak saat berinteraksi. Hal tersebut memotivasi ibu yang sebelumnya cenderung pasif dalam berinteraksi untuk lebih dapat mengikuti minat dan tingkat keaktifan anak.
\end{abstract}

Kata kunci: DIR/Floortime; Circle of Communication; functional emotional development; Autism Spectrum Disorder

\section{DIR/FLOORTIME TO INCREASE COMMUNICATION BETWEEN A CHILD WITH AUTISM AND A MOTHER WITH DIFFERENT SENSORY PROFILE}

\begin{abstract}
The deficit in communication is one of the main features of Autism Spectrum Disorder. Children with ASD tend to have sensory challenges that aggravates their deficit in their ability to communicate. They need caregivers to help them self-regulate to engage in communication with others. One of the interventions that often used to increase communication skill in children with ASD is called Developmental, Individual Differences, Relationship (DIR)/Floortime. DIR/Floortime intervention focuses on children's individual differences, functional emotional development and relationship. Thus, this study aims to evaluate the effectiveness of DIR/Floortime approach to increase communication between a child with ASD and a mother with different sensory profile. Single case design with multiple baselines across situations was used to evaluate the effectiveness of DIR/Floortime in two settings: free and semi-structured play. Circle of Communication Observation Form was used to measure the frequencies of communication between a child and mother. The Functional Emotional Assesment Scale was used to assess and measure the child's and the mother's functional emotional development capacity. The results indicated that DIR/Floortime is effective to increase the frequency and quality of communication in a 4 years-and 2 months old child with ASD. Upon receiving the intervention, the child more often makes eye contact, initiates communication and responds verbally, and more engaged with the mother. Mother's involvement in the intervention makes her immediately notice the child's positive changes during interaction. It motivates the mother who previously tends to be passive to become more active in following the child's interest and level of activity.
\end{abstract}

Keyword: DIR/Floortime; Circle of Communication; functional emotional development; Autism Spectrum Disorder

\section{PENDAHULUAN}

Autism Spectrum Disorder (ASD) merupakan gangguan perkembangan yang salah satu karakteristik utamanya adalah kesulitan dalam menjalin komunikasi dua arah (APA, 2013 Hedenbro \& Tjus, 2007; Yoder \& Stone, 2006). Komunikasi merupakan perilaku bertu- juan yang melibatkan kemampuan inisiasi joint attention, melakukan permintaan, dan perilaku bergantian. Akan tetapi, anak dengan ASD menunjukkan minimnya kemampuan-kemampuan tersebut (Yoder \& Stone, 2006). Hal tersebut tampak saat anak menunjukkan perilaku memberikan respon, menginisiasi interaksi, dan mempertahankan lingkar komunikasi. Umumnya, anak dengan 
ASD hanya melakukan komunikasi yang terbatas pada pemenuhan kebutuhan, tanpa adanya ketertarikan untuk melakukan interaksi sosial lebih lanjut dengan orang lain (Lal \& Chhabria, 2013). Padahal, komunikasi dua arah merupakan faktor yang membantu perkembangan bahasa, interaksi interpersonal, dan sebagai gerbang bagi anak untuk mendapatkan pembelajaran awal (Morgan, et al., 2014).

Komunikasi dua arah terjadi ketika pihak yang telibat saling memberikan respons baik secara verbal maupun nonverbal (Greenspan \& Wieder, 2006) Komunikasi dua arah digambarkan sebagai circle of communication (CoC). Pada $\mathrm{CoC}$, terdapat komponen opening, closing, dan continuing. Sebagai contoh, anak sedang memegang mainan kemudian anak melihat ke arah ibu dan tersenyum (opening $\mathrm{CoC}$ ). Ibu memberikan respons dengan tersenyum balik kepada anak (continuing $\mathrm{CoC}$ ). Kemudian, anak kembali memberikan respons dengan memberikan mainan kepada ibu atau melihat ke arah ibu (closing $\mathrm{CoC}$ ). Apabila opening $\mathrm{CoC}$ terus menerus terjadi tanpa adanya continuing atau closing, maka komunikasi dianggap tidak terjalin karena pesan dalam komunikasi tidak tersampaikan (Greenspan \& Wieder, 1998). Sebagai contoh, jika seorang ibu berulang kali memanggil anak atau menunjukkan mainan kepada anak, namun anak tidak memberikan respons.

Greenspan, DeGangi, Wieder (2001) menyatakan bahwa setiap anak dengan gangguan ASD memiliki profil kelebihan dan kelemahan yang unik dalam hal kognitif, sensori, afektif, dan sosial yang berkaitan dengan kemampuannya dalam berkomunikasi. Keunikan profil anak, khususnya profil sensori, juga berpengaruh terhadap perilaku sehari-hari. Anak dengan kebutuhan sensori yang tinggi cenderung tampak mudah mengalihkan perhatian dan aktif bergerak untuk mendapatkan sensasi yang diinginkan, baik itu sensasi gerak, suara, visual, atau taktil. Sebaliknya, anak dengan sensitivitas tinggi cenderung pasif karena menghindari sensasi (Greenspan \& Salmon, 1995; ICDL, 2002).

Pada dasarnya, setiap individu termasuk anak dengan perkembangan tipikal memiliki profil sensori yang berbeda satu sama lain. Hanya saja, anak dengan ASD memiliki kondisi biologis yang atipikal terkait sensitivitas dan pemrosesan stimulus. Stimulus dengan tingkat yang tergolong normal bagi anak tipikal dinilai sebagai sesuatu yang berlebihan bagi anak dengan ASD sehingga mereka kesulitan dan membutuhkan bantuan orang lain untuk meregulasi diri (Marco, Hinkley, Hill, Nagarajan, 2011). Padahal kemampuan regulasi diri merupakan hal yang penting sebelum anak mampu menjalin komunikasi dengan orang lain. Saat anak kesulitan meregulasi diri akibat kebutuhan sensorinya tidak terpenuhi, anak akan semakin mengabaikan lingkungan sekitarnya (Greenspan \& Salmon, 1995).

Berbagai penelitian menunjukkan pentingnya peran ibu dalam penerapan intervensi bagi anak dengan ASD (Nelson, 2013; Lindgren \& Doobay, 2011; Siller \& Sigman, 2002). Salah satu peranan ibu dalam proses intervensi adalah membangun hubungan yang selaras dengan anak. Hubungan yang selaras tercapai jika orangtua mampu menyesuaikan cara berinteraksi dengan minat dan kebutuhan sensori khusus pada anaknya. Melalui hubungan yang selaras, ibu dapat membantu anak untuk meregulasi diri serta meningkatkan kesiapan anak untuk berinteraksi dengan dunia di luar dirinya melalui peningkatan joint attention (Siller \& Sigman, 2002).

Adanya perbedaan profil sensori pada setiap individu tidak mengharuskan profil sensori ibu sama dengan anak untuk menciptakan hubungan yang selaras. Akan tetapi, Ibu perlu memanfaatkan kepekaan dan pengetahuan yang dimiliki terkait perbedaan profil sensori untuk menyesuaikan diri dengan anak. Apabila ibu tidak dapat menyesuaikan diri dengan kebutuhan sensori dan minat anak, maka ibu juga kurang dapat membantu anak untuk meregulasi diri sehingga anak akan mengabaikan dunia di luar dirinya dan kesulitan menjalin komunikasi (Greenspan \& Salmon, 1995; Greenspan, 2006).

Beberapa penelitian terdahulu menyatakan bahwa salah satu intervensi yang efektif untuk meningkatkan komunikasi dua arah pada anak dengan ASD adalah DIR/Floortime (Dionne \& Martini, 2011; Hess, 2013; Lal \& Chhabria, 2013; Paul, 2008). Berdasarkan Greenspan dan Wieder (2006), intervensi floortime menggunakan pendekatan DIR (Development, Individual difference, dan Relationship), yaitu mempertimbangkan perkembangan dan profil keunikan sensori masing-masing anak sehingga sangat disesuaikan dengan kondisi dan kebutuhan masing-masing anak. Intervensi ini juga melibatkan pengasuh utama untuk berperan aktif dalam program yang dijalankan.

Model DIR memeriksa kapasitas functional emotional development anak pada konteks keunikan profil biologis dan dinamika interaksi anak dengan keluarganya. Komponen "D" mengacu pada kapasitas perkembangan anak yang didasarkan pada 6 level functional emotional development (Greenspan \& Wieder, 2009). Keenam level tersebut yaitu regulation and interest in the world (level 1), engaging and relating (level 2), intentionality and two-ways communication (level 3), social problem-solving, mood regulation, and formation of a sense of self (level 4), creating symbols and using words and ideas (level 5), dan emotional thinking, logic, and a sense of reality (level 6) (Greenspan \& Wieder, 2009; ICDL, 2005). 
Komponen "I" mengacu pada individual differences atau keunikan pada masing-masing individu terkait kemampuan indera dalam memproses informasi sensori dan meregulasi diri (Greenspan \& Wieder, 2009). Komponen " $\mathrm{R}$ " mengacu pada relationship, yaitu hubungan anak dengan lingkungan keluarga. Keluarga sebagai lingkungan terdekat anak berperan dalam menyediakan interaksi yang dapat memfasilitasi anak untuk mengembangkan kapasitas perkembangan kognitif, sosial, dan emosionalnya (Wieder \& Greenspan, 2003).

Floortime merupakan teknik intervensi yang menggunakan model DIR. Secara teknis, floortime merupakan aktivitas dimana orang dewasa yang terlibat interaksi dengan anak (orangtua, pengasuh, terapis, guru, dan lainnya) dilatih untuk dapat secara efektif menjalin komunikasi dua arah melalui bermain di lantai bersama anak selama setidaknya 20 menit (Hess, 2013). Meski demikian, pelaksanaan floortime tidak terbatas pada bermain di lantai, namun membebaskan anak untuk main sesuai dengan minatnya (Greenspan\& Wieder, 2006). Tujuan utama dari program intervensi floortime adalah mengoptimalkan perkembangan anak sesuai dengan keenam tahap functional emotional development (Wieder \& Greenspan, 2003).

Secara lebih spesifik, Floortime memiliki dua tujuan utama. Tujuan pertama adalah mengikuti arahan atau minat anak dalam bermain. Hal itu didasari pertimbangan bahwa dengan mengikuti minat anak, pengasuh dapat mengobservasi dan memahami emosi dan cara berpikir anak, seperti apa yang membuat mereka nyaman atau termotivasi (Greenspan \& Wieder, 2009). Dengan memahami apa yang diminati anak, pengasuh lebih dapat memasuki dunia anak. Tujuan kedua yaitu membawa anak ke dunia yang sama dengan orang lain (shared world) sehingga anak tidak hanya berfokus pada dunianya. Apabila pengasuh dapat memasuki dunia anak melalui hal yang anak minati, maka anak akan merasa lebih dekat dengan pengasuh dan akan menunjukkan ketertarikan untuk berinteraksi. Melalui interaksi yang terjalin, diharapkan anak dapat mengoptimalkan perkembangannya pada keenam tahap functional emotional development (Greenspan \& Wieder, 2009).

Sebelumnya telah dilakukan beberapa penelitian mengenai penerapan DIR/Floortime di Indonesia. Penelitian-penelitian tersebut membahas penerapan DIR/Floortime untuk meningkatkan komunikasi pada anak dengan ASD pada berbagai rentang usia (Boediman \& Mardian, 2017; Phandinata, Atmodiwirjo, \& Lumbanbatu, 2015; Santoso, 2019). Meski demikian, penelitian-penelitian tersebut hanya berfokus pada karakteristik khas anak dan kurang mengangkat profil keunikan ibu yang akan terlibat dalam komunikasi dua arah. Padahal, profil ibu juga berperan penting dalam pola interaksi antara anak dengan ibu (Greenspan \& Wieder, 2009). Melalui penelitian ini, peneliti ingin mengetahui efektivitas penerapan DIR/ Floortime dalam meningkatkan komunikasi dua arah pada anak dengan autisme dan secara spesifik mengangkat profil sensori anak dan ibu yang berbeda. Penelitian ini juga akan membandingkan penerapan DIR/floortime untuk meningkatkan komunikasi dua arah di setting free dan semi-structured play. Berdasarkan Greenspan \& Wieder (2006), DIR/Floortime tidak hanya dapat diterapkan pada setting bermain bebas, namun sebaiknya juga diterapkan pada aktivitas yang lebih terstruktur agar dapat lebih tergeneralisasi di kehidupan sehari-hari.

\section{METODE}

Desain penelitian yang digunakan yaitu single subject design. Pengukuran dependent variable dilakukan dengan cara multiple baseline across situations, yaitu mengevaluasi treatment terhadap satu perilaku yang tampak pada dua situasi (Gravetter \& Forzano, 2012). Dalam penelitian ini, desain tersebut bertujuan untuk mengevaluasi penerapan prinsip DIR/Floortime terhadap komunikasi dua arah pada situasi bermain bebas (free play) dan semi-structured play. Peningkatan komunikasi dua arah dilihat dari adanya peningkatan circle of communication ( $\mathrm{CoC})$.

Partisipan adalah anak laki-laki berusia 4 tahun 2 bulan. Anak mendapatkan pemeriksaan psikologis saat berusia 3 tahun 10 bulan dan didiagnosis mengalami Autism Spectrum Disorder (ASD) level 2. Anak kurang menunjukkan adanya minat untuk melakukan interaksi sosial di luar pemenuhan kebutuhannya. Saat berinteraksi, bentuk komunikasi yang ia lakukan terbatas pada komunikasi nonverbal. Anak cukup memiliki banyak kosa kata namun hanya digunakan untuk melabel benda-benda yang ia lihat dan tidak digunakan untuk berinteraksi dengan orang lain. Selain itu, ia memiliki kebutuhan sensori gerak yang tinggi sehingga cenderung banyak bergerak dan lebih menyukai kegiatan yang melibatkan banyak pergerakan, seperti lempar tangkap bola, memanjat, dan melompat. Pada kemampuan motorik halus, anak masih menggenggam crayon atau pensil dengan cara digenggam, bingung saat memegang sendok, dan kesulitan melakukan kegiatan visual motorik halus lainnya.

Partisipan ibu berusia 30 tahun merupakan pengasuh utama dan menghabiskan sebagian besar waktunya bersama anak. Ibu berprofesi sebagai penerjemah dan bekerja dari rumah. Biasanya ibu sibuk dengan pekerjaannya saat jam kerja pada umumnya, sehingga hanya banyak berinteraksi dengan anak saat istirahat makan siang, sore, dan malam hari. Interaksi yang yang ibu 
dilakukan dengan anak pun minim karena anak lebih banyak fokus dengan gadget. Saat berinteraksi, ibu hanya akan meminta anak untuk melabel sesuatu atau menunjuk benda yang ibu sebut. Saat anak aktif bergerak, ibu hanya akan melihatnya dari jauh dan hanya akan memanggil anak meski kerap diacuhkan. Sesekali, ibu mengikuti pergerakan anak atau terlibat permainan lempar tangkap bola, namun hal tersebut tidak berlangsung lama. Pada kesehariannya, ibu memang lebih menikmati aktivitas yang tidak melibatkan banyak bergerak, sehingga saat bermain pun ibu lebih memilih dengan cara duduk atau tiduran.

Terdapat dua jenis instrumen yang digunakan dalam penelitian ini, yaitu instrumen utama dan instrumen pelengkap. Instrumen utama yang digunakan akan dijelaskan sebagai berikut:

\section{a. Lembar observasi Circle of Communication (CoC)}

Lembar observasi Circle of Communication (CoC) dibuat oleh tim peneliti dan digunakan untuk mencatat frekuensi $\mathrm{CoC}$ yang dilakukan oleh anak. Lembar observasi CoC mencakup sesi, aktivitas bermain (free dan semi-structured play), frekuensi open anak (inisiasi yang anak lakukan baik verbal maupun nonverbal) dan jumlah keseluruhan frekuensi $\mathrm{CoC}$ (iniasiasi yang dibalas dengan respons, baik verbal maupun nonverbal) dalam satu sesi.

Uji validitas alat ukur dilakukan dengan teknik content validity, yaitu dengan meminta expert judgement terhadap konten dari alat ukur. Berdasarkan hasil expert judment, terdapat beberapa perubahan konten sehingga alat ukur cukup mewakili perhitungan $\mathrm{CoC}$. Uji reliabilitas lembar observasi $\mathrm{CoC}$ dilakukan melalui interrater agreement dengan teknik intraclass correlation (ICC). Hasilnya, alat ukur ini memenuhi kaidah reliabilitas $([I C C]=0,825-0,990, p>0,05)$.

\section{b. Functional Emotional Assessment Scale (FEAS)}

Alat ukur ini mengukur keberfungsian emosional dan sosial anak berdasarkan tahapan functional emotional development (Greenspan, DeGangi, Wieder, 2001). Pengisian FEAS juga dilakukan terhadap ibu untuk mengetahui sejauh mana kemampuan ibu untuk membantu meningkatkan kapasitas perkembangan anak. Pengisian FEAS dilakukan berdasarkan observasi interaksi anak dengan ibu saat bermain selama 30 menit pada saat pretest dan posttest.

Berdasarkan Greenspan, DiGangi, dan Wieder (2001), alat ukur FEAS telah memenuhi kaidah reliabilitas dan validitas. Sebelum digunakan pada penelitian ini, peneliti menerjemahkan item-item alat ukur ke Bahasa Indonesia. Uji content validity dilakukan dengan meminta expert judgement mengenai item alat ukur yang telah diterjemahkan. Berdasarkan uji validitas, terdapat beberapa item yang diubah agar lebih dapat dipahami. Uji reliabilitas FEAS dilakukan melalui interrater agreement dengan teknik intraclass correlation (ICC). Hasilnya, alat ukur FEAS untuk anak memenuhi kaidah reliabilitas $([\mathrm{ICC}]=0,991-1,000, \mathrm{p}>0,05)$. Begitu pula dengan FEAS untuk ibu $([\mathrm{ICC}]=0,994-0,999$, $\mathrm{p}>0,05)$.

Instrumen pelengkap digunakan dalam penelitian ini untuk mendapatkan gambaran profil biologis anak dan ibu yang dapat berpengaruh terhadap interaksi anak dengan ibu. Instrumen yang digunakan, yaitu:

\section{a. Sensory Processing/Motor Planning Questionnaire (SPMPQ)}

Kuisioner SPMPQ (Greenspan, 2000) merupakan alat ukur yang biasa digunakan dalam intervensi floortime untuk mengetahui profil sensori ibu yang terlibat dalam pelaksanaan intervensi. SPMPQ diisi oleh peneliti dengan mewawancarai ibu. Profil sensori ibu perlu diketahui karena hal itu dapat mempengaruhi cara interaksi ibu dengan anak.

\section{b. Short Sensory Profile}

Alat ukur short sensory profile telah diadaptasi oleh Yudhiatmoko (2014) ke dalam Bahasa Indonesia. Alat ukur ini juga telah memenuhi kaidah validitas dan reliabilitas sehingga telah sesuai untuk memperoleh profil sensori pada anak di Indonesia. Pengisian short sensory profile dilakukan oleh orangtua untuk mendapatkan gambaran profil sensori anak yang mencakup sensitivitas taktil, perasa dan pembau, pergerakan, visual auditori, tingkat energi, dan kemampuan filter auditori.

Secara umum, penelitian terbagi ke dalam tiga bagian, yaitu tahap pra-intervensi, intervensi, dan post-intervensi. Program intervensi yang dilakukan pada penelitian ini telah melalui kaji etik oleh Komite Etik Universitas Indonesia. Peneliti juga telah memberikan informed consent untuk mendapatkan persetujuan partisipan.

Pengambilan data baseline dilakukan pada setting free dan semi-stuctured play. Baseline pada setting free play dilakukan selama 3 sesi sedangkan semi-structured play selama 7 sesi. Free play merupakan aktivitas dimana anak dan ibu melakukan permainan bebas seperti yang biasa mereka lakukan tanpa adanya struktur yang diberikan. Sementara itu, aktivitas pada setting semi-structured play telah dirancang sebelumnya oleh peneliti berdasarkan kebutuhan anak, yaitu untuk meningkatkan kemampuan motorik halus. Selama baseline, peneliti melakukan pengisian lembar observasi $\mathrm{CoC}$, FEAS, serta mengambil data mengenai profil sensori partisipan.

Psikoedukasi diberikan selama dua sesi karena ibu dilibatkan secara aktif selama pelaksanaan program. 
Tujuan dari psikoedukasi adalah memberikan gambaran yang lebih terperinci mengenai pelaksanaan intervensi DIR/Floortime, jumlah sesi, tujuan dari masing-masing sesi, serta pentingnya pemahaman mengenai profil sensori dan keterlibatan ibu untuk mengoptimalkan perkembangan anak. Peneliti juga melakukan roleplay bersama ibu untuk melatih kemampuan ibu dalam mengaplikasikan DIR/Floortime.

Tabel 1. Ringkasan Kegiatan Intervensi

\begin{tabular}{|c|c|c|c|}
\hline \multicolumn{4}{|c|}{ Free Play } \\
\hline \multirow[t]{2}{*}{ Sesi } & \multirow[t]{2}{*}{ Kegiatan } & \multicolumn{2}{|c|}{ Target } \\
\hline & & Kuantitafif & Kualitatif \\
\hline 1 & \multirow{10}{*}{$\begin{array}{l}\text { Ibu dan anak } \\
\text { menerapkan } \\
\text { pendekatan DIR/ } \\
\text { Floortime pada } \\
\text { permainan sensori } \\
\text { dan simbolik. } \\
\text { Peneliti melaku- } \\
\text { kan supervisi dan } \\
\text { memberi evaluasi }\end{array}$} & $\begin{array}{l}\mathrm{CoC} \text { meningkat } \\
5 \%\end{array}$ & FEAS level 1 \\
\hline 2 & & $\begin{array}{l}\text { CoC meningkat } \\
10 \%\end{array}$ & FEAS level 1 \\
\hline 3 & & $\begin{array}{l}\mathrm{CoC} \text { meningkat } \\
15 \%\end{array}$ & FEAS level 1-2 \\
\hline 4 & & $\begin{array}{l}\text { CoC meningkat } \\
20 \%\end{array}$ & FEAS level 2 \\
\hline 5 & & $\begin{array}{l}\mathrm{CoC} \text { meningkat } \\
25 \%\end{array}$ & FEAS level 2-3 \\
\hline 6 & & $\begin{array}{l}\text { CoC meningkat } \\
30 \%\end{array}$ & FEAS level 3 \\
\hline 7 & & $\begin{array}{l}\text { CoC meningkat } \\
35 \%\end{array}$ & FEAS level 3-4 \\
\hline 8 & & $\begin{array}{l}\text { CoC meningkat } \\
40 \%\end{array}$ & FEAS level 4 \\
\hline 9 & & $\begin{array}{l}\text { CoC meningkat } \\
45 \%\end{array}$ & FEAS level 4-5 \\
\hline 10 & & $\begin{array}{l}\mathrm{CoC} \text { meningkat } \\
50 \%\end{array}$ & FEAS level 5 \\
\hline 11 & \multirow[t]{2}{*}{ Generalisasi } & \multirow{2}{*}{\multicolumn{2}{|c|}{ Mempertahankan target di sesi terakhir }} \\
\hline 12 & & & \\
\hline
\end{tabular}

Semi-Structured Play

\begin{tabular}{|c|c|c|c|}
\hline \multirow{2}{*}{ Sesi } & \multirow{2}{*}{ Kegiatan } & \multicolumn{2}{|c|}{ Target } \\
\hline & & Kuantitatif & Kualitatif \\
\hline 1 & \multirow{4}{*}{$\begin{array}{l}\text { M e l a n j u t k a n } \\
\text { baseline sesi 4-7 }\end{array}$} & \multirow{4}{*}{\multicolumn{2}{|c|}{-}} \\
\hline 2 & & & \\
\hline 3 & & & \\
\hline 4 & & & \\
\hline 5 & \multirow{6}{*}{$\begin{array}{l}\text { Ibu dan anak } \\
\text { menerapkan } \\
\text { pendekatan } \\
\text { DIR/Floortime } \\
\text { pada permainan } \\
\text { semi-strcutured. } \\
\text { Peneliti melaku- } \\
\text { kan supervisi } \\
\text { dan memberi } \\
\text { evaluasi }\end{array}$} & CoC meningkat $25 \%$ & FEAS level 1 \\
\hline 6 & & CoC meningkat $30 \%$ & FEAS level 1-2 \\
\hline 7 & & CoC meningkat $35 \%$ & FEAS level 1-2 \\
\hline 8 & & CoC meningkat $40 \%$ & FEAS level 2-3 \\
\hline 9 & & CoC meningkat $45 \%$ & FEAS level 3-4 \\
\hline 10 & & CoC meningkat $50 \%$ & FEAS level 4-5 \\
\hline 11 & \multirow{2}{*}{ Generalisasi } & \multirow{2}{*}{\multicolumn{2}{|c|}{ Mempertahankan target di sesi terakhir }} \\
\hline 12 & & & \\
\hline
\end{tabular}

Tahap intervensi dilakukan selama 12 sesi yang dibagi menjadi 10 sesi dilakukan di klinik dan 2 sesi generalisasi di rumah partisipan. Pada setiap sesi, ibu dan anak bermain dengan menerapkan prinsip DIR/ Floortime pada setting free dan semi-structured play dengan supervisi dari peneliti. Pelaksanaan setiap sesi disesuaikan dengan target kuantitatif dan kualitatif yang disesuaikan dengan tahapan functional emotional development.

Posttest dilakukan selama tiga sesi. Pada sesi terakhir, peneliti melakukan debriefing sekaligus mewawancarai ibu untuk menggali perasaan dan pandangan ibu mengenai proses intervensi yang telah dijalani, serta mengenai perubahan kemampuan interaksi antara ibu dan anak. Follow up dilakukan empat minggu setelah sesi terakhir untuk melihat kuantitas dan kualitas komunikasi setelah tidak lagi diberikan intervensi. Berikut merupakan ringkasan kegiatan intervensi.

Evaluasi hasil penelitian ini menggunakan analisis visual dengan melihat perbandingkan pergerakan data yang dituangkan dalam grafik. Analisis dilakukan dengan melihat change in trend saat pretest (baseline) dan posttest untuk melihat perubahan $\mathrm{CoC}$ dan functional emotional development yang terjadi setelah pemberian intervensi. Program dinyatakan efektif apabila terdapat peningkatan trendline pada grafik $\mathrm{CoC}$ dan functional emotional development.

\section{HASIL DAN PEMBAHASAN}

Terdapat peningkatan trendline pada kuantitas open di setting free play maupun semi-structured play. Hal itu menandakan bahwa kemampuan anak dalam menginisiasi interaksi cenderung meningkat setelah diberikan intervensi dibandingkan saat baseline. Di samping itu, peningkatan trendline pada jumlah $\mathrm{CoC}$ menandakan bahwa jumlah komunikasi dua arah antara anak dengan ibu pun meningkat setelah diberikan intervensi.

Rata-rata kuantitas inisiasi interaksi yang anak lakukan (open $\mathrm{CoC}$ ) dan jumlah komunikasi dua arah antara anak dengan ibu (jumlah $\mathrm{CoC}$ ) baik pada setting free play maupun semi-structured play mengalami peningkatan. Pada setting free play, peningkatan open CoC terjadi sebesar $114 \%$ dan memenuhi target minimal 50\%. Hanya saja, peningkatan jumlah $\mathrm{CoC}$ hanya sebesar $36 \%$ atau tidak memenuhi target. Pada setting semi-structured play, peningkatan open $\mathrm{CoC}$ sebesar $112 \%$ dan jumlah CoC sebesar $85 \%$. 


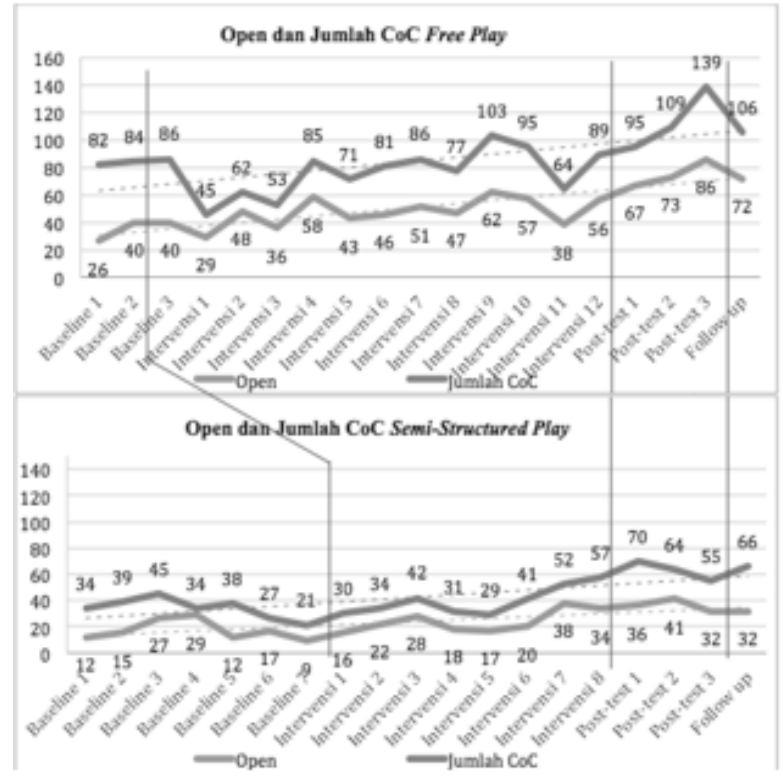

Gambar 1. Perbandingan Open dan Jumlah CoC pada Setting Free dan Semi-Structured Play

Berikut merupakan hasil pengukuran skor FEAS pada anak:

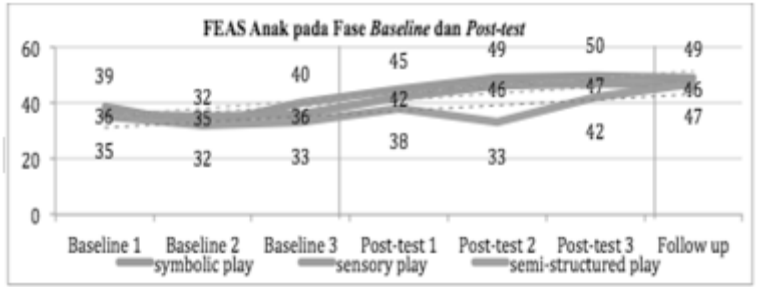

Gambar 2. Skor FEAS Anak Saat Baseline, Post-test, dan Follow-Up

Secara umum, terdapat peningkatan skor FEAS anak setelah diberikan intervensi dibandingkan saat sebelum intervensi, baik pada aktivitas permainan simbolik, sensori, maupun semi-structured. Secara lebih detail, setelah diberikan intervensi, pencapaian functional emotional anak hanya tergolong normal pada permainan simbolik. Selain itu, secara umum kapasitas representasi melalui pretend play (level 5) anak masih tergolong deficit.

Tabel 2. Pencapaian Tingkat Functional Emotional Development Anak

\begin{tabular}{|c|c|c|c|c|c|c|c|c|c|}
\hline \multirow{2}{*}{ 离 } & \multicolumn{3}{|c|}{ Baseline } & \multicolumn{3}{|c|}{ Post-test } & \multicolumn{3}{|c|}{ Follow- $U_{p}$} \\
\hline & 脑 & $\underset{\varpi}{a}$ & $\underset{n}{\stackrel{n}{n}}$ & 脑 & 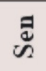 & 䍃 & 泣 & ڤี & $\underset{n}{\stackrel{n}{n}}$ \\
\hline 1 & $\mathrm{~N}$ & $\mathrm{~N}$ & $\mathrm{~N}$ & $\mathrm{~N}$ & $\mathrm{~N}$ & $\mathrm{~N}$ & $\mathrm{~N}$ & $\mathrm{~N}$ & $\mathrm{~N}$ \\
\hline 2 & $\mathrm{~A}$ & $\mathrm{~N}$ & $\mathrm{~A}$ & $\mathrm{~N}$ & $\mathrm{~N}$ & $\mathrm{~A}$ & $\mathrm{~N}$ & $\mathrm{~N}$ & $\mathrm{~N}$ \\
\hline 3 & $\mathrm{~A}$ & $\mathrm{~N}$ & $\mathrm{D}$ & $\mathrm{N}$ & $\mathrm{N}$ & $\mathrm{D}$ & $\mathrm{N}$ & $\mathrm{N}$ & $\mathrm{N}$ \\
\hline 4 & $\mathrm{D}$ & $\mathrm{D}$ & $\mathrm{N}$ & $\mathrm{N}$ & $\mathrm{N}$ & $\mathrm{D}$ & $\mathrm{N}$ & $\mathrm{N}$ & $\mathrm{N}$ \\
\hline 5 & $\mathrm{D}$ & $\mathrm{D}$ & $\mathrm{D}$ & $\mathrm{D}$ & $\mathrm{D}$ & $\mathrm{D}$ & $\mathrm{D}$ & $\mathrm{D}$ & $\mathrm{D}$ \\
\hline 6 & $\mathrm{D}$ & $\mathrm{D}$ & $\mathrm{D}$ & $\mathrm{D}$ & $\mathrm{D}$ & $\mathrm{D}$ & $\mathrm{D}$ & $\mathrm{D}$ & $\mathrm{D}$ \\
\hline Total & D & D & D & $\mathbf{N}$ & A & D & $\mathbf{N}$ & $\mathrm{A}$ & $\mathrm{A}$ \\
\hline
\end{tabular}

Sym: Permainan simbolik, Sen: Permainan sensori, STR: Permainan semi-structured

N: Normal, A: At risk, D: Deficient
Pada permainan simbolik, terdapat peningkatan pencapaian functional emotional anak setelah diberikan intervensi. Pada fase pretest, anak mampu meregulasi diri (level 1) namun tingkat functional emotional lainnya belum tercapai. Setelah diberikan intervensi, tingkat functional emotional anak secara umum tergolong normal. Anak mampu meregulasi diri (level 1), meningkatkan kelekatan dengan ibu (level 2), terlibat dalam komunikasi dua arah (level 3), serta melakukan komunikasi dua arah dalam memecahkan masalah (level 4). Kemampuan tersebut bertahan hingga fase follow up.

Pada aktivitas permainan sensori di fase pretest, anak mampu meregulasi diri (level 1), engage dengan ibu (level 2), serta menampakkan komunikasi dua arah dengan ibu (level 3). Pada fase posttest, anak mulai mampu melakukan komunikasi dua arah dalam memecahkan masalah (level 4). Meski demikian, secara umum skor yang diperoleh anak pada permainan sensori tergolong at risk. Kondisi itu pun bertahan hingga pada fase follow up.

Berbeda dengan dua jenis permainan lainnya, tingkat functional emotional anak pada permainan semi-structured tetap dalam kategori deficient meski telah diberikan intervensi. Anak mampu meregulasi diri (level 1), namun belum mencapai tingkat functional emotional lainnya. Akan tetapi, terjadi peningkatan pada sesi follow up. Anak mampu meregulasi diri (level 1), meningkatkan kelekatan dengan ibu (level 2), terlibat dalam komunikasi dua arah (level 3), serta melakukan komunikasi dua arah dalam memecahkan masalah (level 4). Hanya saja total skor yang diperoleh pada sesi follow up menunjukkan bahwa secara umum functional emotional anak masih tergolong at risk.

Selain pengukuran functional emotional development anak, dilakukan pula pengukuran hal yang sama terhadap ibu. Terdapat peningkatan skor FEAS ibu pada fase posttest dibandingkan dengan skor pada fase pretest, baik pada aktivitas permainan simbolik, sensori, maupun semi-structured. Seperti pengukuran skor FEAS anak, skor FEAS ibu pada fase follow-up pada aktivitas permainan simbolik dan semi-structured pun meningkat dibandingkan fase post-test, namun skor pada aktivitas permainan sensori sedikit menurun dibandingkan saat post-test. Meski demikian, dapat terlihat pada tabel 3 bahwa setelah pemberian intervensi, pencapaian functional emotional ibu baik pada aktivitas permainan simbolik, sensori, maupun semi-structured secara umum tergolong normal. Kondisi itu pun bertahan pada fase follow up.

Pada permainan simbolik, sebelum diberikan intervensi, ibu menunjukkan kapasitas functional emotional yang baik dalam membantu anak meregulasi diri 
(level 1: normal) serta upaya menjalin engagement dengan anak (level 2: normal). Setelah diberikan intervensi, functional emotional ibu pada permainan simbolik dan sensori tergolong normal pada level 1 hingga 4. Artinya, setelah intervensi, ibu mampu membantu anak untuk meregulasi diri, menjalin kelekatan, terlibat dalam komunikasi dua arah, serta melakukan komunikasi dua arah dalam pemecahan masalah. Kondisi ini tetap bertahan pada sesi follow-up.

Tabel 3. Pencapaian Tingkat Functional Emotional Development Ibu

\begin{tabular}{|c|c|c|c|c|c|c|c|c|c|}
\hline \multirow[b]{2}{*}{ 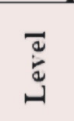 } & \multicolumn{3}{|c|}{ Baseline } & \multicolumn{3}{|c|}{ Post-test } & \multicolumn{3}{|c|}{ Follow- $C p$} \\
\hline & 脑 & a & $\underset{n}{\stackrel{n}{*}}$ & 汸 & ڤ్ & $\underset{n}{\stackrel{n}{G}}$ & 脑 & $\begin{array}{l}\vec{a} \\
\text { n. }\end{array}$ & 光 \\
\hline 1 & $\mathrm{~N}$ & $\mathrm{~N}$ & $\mathrm{~N}$ & $\mathrm{~N}$ & $\mathrm{~N}$ & $\mathrm{~N}$ & $\mathrm{~N}$ & $\mathrm{~N}$ & $\mathrm{~N}$ \\
\hline 2 & $\mathrm{~N}$ & $\mathrm{~N}$ & $\mathrm{~N}$ & $\mathrm{~N}$ & $\mathrm{~N}$ & $\mathrm{~N}$ & $\mathrm{~N}$ & $\mathrm{~N}$ & $\mathrm{~N}$ \\
\hline 3 & $\mathrm{D}$ & D & $\mathrm{A}$ & $\mathrm{N}$ & $\mathrm{N}$ & $\mathrm{N}$ & $\mathrm{N}$ & $\mathrm{N}$ & $\mathrm{N}$ \\
\hline 4 & $\mathrm{D}$ & $\mathrm{D}$ & $\mathrm{D}$ & $\mathrm{N}$ & $\mathrm{N}$ & $\mathrm{D}$ & $\mathrm{N}$ & $\mathrm{A}$ & $\mathrm{N}$ \\
\hline 5 & $\mathrm{D}$ & $\mathrm{D}$ & $\mathrm{D}$ & A & $\mathrm{D}$ & $\mathrm{D}$ & $\mathrm{A}$ & D & $\mathrm{D}$ \\
\hline 6 & $\mathrm{D}$ & $\mathrm{D}$ & $\mathrm{D}$ & $\mathrm{D}$ & $\mathrm{D}$ & $\mathrm{D}$ & $\mathrm{D}$ & $\mathrm{D}$ & $\mathrm{D}$ \\
\hline Total & D & D & D & $\mathrm{N}$ & $\mathbf{N}$ & $N$ & $\mathrm{~N}$ & $\mathrm{~N}$ & $\mathrm{~N}$ \\
\hline
\end{tabular}

Sym: Permainan simbolik, Sen: Permainan sensori, STR:

Permainan semi-structured

N: Normal, A: At risk, D: Deficient

Pada aktivitas permainan sensori, pencapaian functional emotional ibu pada tahap baseline dan posttest tergolong sama seperti pada permainan simbolik (level 1-4: normal). Meski demikian, pada sesi follow $u p$, terjadi penurunan kemampuan ibu dalam memfasilitasi anak melakukan komunikasi dua arah untuk memecahkan masalah (level 4: at risk).

Sementara itu, setelah diberikan intervensi pada aktivitas permainan semi-structured, ibu masih kesulitan memfasilitasi anak untuk melakukan komunikasi dua arah untuk memecahakan masalah (level 4: deficient). Akan tetapi, kemampuan tersebut meningkat saat sesi follow up.

Hasil penelitian menunjukkan adanya peningkatan kemampuan anak dalam melakukan inisiasi dan memberikan respon dalam melakukan komunikasi dua arah dengan ibu. Hal tersebut dilihat dari peningkatan persentase kuantitas inisiasi komunikasi (open) dan jumlah CoC. Secara umum, peningkatan kuantitas inisiasi komunikasi oleh anak (open) pada setting free play sebesar $114 \%$. Akan tetapi, peningkatan kuantitas komunikasi dua arah antara anak dengan ibu (jumlah $\mathrm{CoC}$ ) hanya sebesar 36\%. Tingginya jumlah $\mathrm{CoC}$ saat pretest terjadi melalui permainan lempar tangkap bola yang melibatkan banyak pergerakan.

Berdasarkan hasil asesmen profil sensori, anak memang lebih menikmati aktivitas yang melibatkan banyak pergerakan. Hanya saja, selama sesi intervensi, anak tidak lagi terlalu tertarik bermain bola. Meski jumlah $\mathrm{CoC}$ yang terjalin saat pretest cukup tinggi, kualitas interaksi yang terjalin tidak optimal karena ibu terlalu banyak memberi arahan pada anak. Berdasarkan Pajareya dan Nopmaneejumruslers (2011), tingginya skor yang diperoleh saat pretest dapat menimbulkan ceiling effect sehingga hasil akhir penelitian dapat menjadi tidak optimal. Akan tetapi, secara kualitas hasil pretest yang rendah memberikan ruang bagi intervensi untuk membantu meningkatkan keterampilan ibu.

Saat intervensi pada setting free play, jumlah $\mathrm{CoC}$ tertinggi terjadi pada sesi 9. Pada sesi tersebut, ibu responsif dan engagament terjalin baik selama sesi. Jumlah $\mathrm{CoC}$ yang paling rendah tampak pada sesi 1 . Hal tersebut karena saat pretest ibu lebih banyak mengarahkan anak. Memasuki sesi intervensi pertama, ibu tampak ragu untuk mengikuti minat bermain anak sehingga kurang tampak menikmati aktivitas bermain. Anak pun cenderung berpindah cepat antarmainan dan kerap mengabaikan ibu. Menurut Greenspan (2007) kondisi ibu yang kurang dapat meregulasi diri dan fokus dalam aktivitas bersama anak membuat ibu tidak sensitif terhadap respon dan minat anak sehingga sulit untuk masuk ke dunia permainan anak.

Penurunan jumlah inisiasi interaksi yang anak lakukan serta jumlah $\mathrm{CoC}$ yang terjalin juga tampak menurun dalam jumlah yang banyak pada sesi 3 dan 11. Pada sesi 3, pelaksanaan intervensi diundur sepuluh hari sejak pelaksanaan sesi sebelumnya karena anak dan ibu sakit. Hal tersebut membuat ibu dan anak kembali menyesuaikan diri dalam menerapkan prinsip DIR/ Floortime seperti sesi 1. Sesi 11 merupakan sesi generalisasi dan mulai melibatkan ayah dalam bermain. Pada sesi ini, ayah masih banyak mengarahkan anak dan memerlukan waktu untuk beradaptasi menerapkan prinsip DIR/Floortime sehingga jumlah komunikasi yang terjalin pun menurun.

Pada setting semi-structured play, kuantitas open maupun jumlah $\mathrm{CoC}$ di setting ini berada jauh dibawah kuantitas open dan jumlah $\mathrm{CoC}$ pada setting free play. Selama intervensi pun anak kerap menolak mengikuti aktivitas semi-structured berupa aktivitas motorik halus. Jika dibandingkan, kuantitas inisiasi (open anak) dan jumlah $\mathrm{CoC}$ pada sesi 4 dan 9 setting free play merupakan yang tertinggi. Meski demikian, pada setting semi-structured play di sesi yang sama (baseline 7 dan intervensi 5), kuantitas open anak dan jumlah $\mathrm{CoC}$ yang terjalin merupakan yang terendah selama intervensi.

Berdasarkan Dionne dan Martini (2011), peningkatan $\mathrm{CoC}$ terkait dengan peningkatan kapasitas perkembangan functional emotional anak. Untuk mem- 
bantu anak menguasai setiap level perkembangan tersebut, penting bagi ibu untuk terlebih dahulu masuk ke dalam dunia permainan anak untuk menjalin keterikatan emosional dengan anak sehingga anak tertarik untuk berbagi dunianya dan menjalin (Hess, 2013). Pada setting free play, ibu mengikuti minat bermain anak sehingga anak well-regulated (level 1) dan engagement yang terjalin dengan ibu pun baik (level 2). Hal tersebut membuat komunikasi dua arah yang terjalin cukup banyak (level 3), bahkan anak menunjukkan kemampuan pemecahan masalah melalui komunikasi (level 4), serta mulai menunjukkan kapasitas representasi simbolik (level 5). Akan tetapi, ketika setting bermain berganti menjadi semi-structured, ibu lebih banyak mengarahkan anak untuk melakukan aktivitas yang telah ditetapkan sehinnga engagement yang terjalin menurun dan anak kembali mengacuhkan ibu.

Selama sesi intervensi di setting semi-structured play, kuantitas inisiasi komunikasi yang anak lakukan dan jumlah komunikasi dua arah yang terjalin paling tinggi pada sesi 7 dan 8 . Kedua sesi tersebut merupakan sesi generalisasi yang dilakukan di rumah. Setting semi-structured dilakukan untuk memudahkan generalisasi penerapan prinsip DIR/Floortime pada kegiatan sehari-hari yang cenderung terstruktur (Greenspan \& Wieder, 2006). Pada kasus ini, anak tampak well-regulated dan terlibat dalam komunikasi dua arah yang cukup panjang di lingkungan rumah. Sementara itu, intervensi pada setting klinis dilakukan di ruang bermain dan selalu didahului oleh free play. Anak dengan ASD cenderung menunjukkan perilaku rigid terkait pola kegiatan yang biasa mereka lakukan sehari-hari (Miles, 2011). Pada kesehariannya, anak memahami pola bahwa lingkungan rumah merupakan lingkungan yang lebih terstruktur dan ibu akan cenderung mengarahkan sementara lingkungan klinik merupakan tempat untuk bermain. Hal tersebut membuat anak lebih mampu meregulasi diri dan menjalin komunikasi melalui aktivitas semi-structured di lingkungan rumah dibandingkan lingkuangan klinik.

Hasil penelitian juga menunjukkan bahwa terdapat peningkatan skor FEAS anak dan ibu yang menandakan adanya peningkatan pencapaian functional emotional anak serta ibu. Hal ini juga sejalan dengan penelitian-penelitian sebelumnya bahwa DIR/Floortime membantu meningkatkan kapasitas functional emotional development anak serta membantu keterampilan ibu dalam membantu anak mengoptimalkan kapasitas functional emotional (Hess, 2013; Dionne \& Martini, 2011). Jika ditinjau lebih lanjut, pergerakan grafik $\mathrm{CoC}$ dengan grafik FEAS cenderung senada. Menurut Greenspan dan Wieder (2006) seiring dengan meningkatnya perkembangan functional emotional, kemampuan anak dalam menjalin komu- nikasi dan interaksi pun akan semakin meningkat.

Terdapat beberapa faktor yang mendukung peningkatan kemampuan anak dalam menjalin komunikasi dua arah setelah diberikan intervensi. Faktor pertama adalah sikap kooperatif dari keluarga, terutama ibu dalam proses intervensi. Pada setiap sesi, ibu berusaha menjalankan saran dari peneliti serta tidak segan untuk bertanya ketika mengalami kesulitan. Hal ini pun terlihat dari peningkatan pola interaksi ibu yang awalnya cenderung pasif menjadi lebih dapat mengikuti minat dan tingkat keaktifan anak. Berdasarkan hasil wawancara, hal utama yang menguatkan niat ibu untuk berubah adalah engagement yang terjalin dengan anak serta peningkatan yang tampak pada anak saat ibu menyelaraskan diri dengan minat dan tingkat keaktifan anak. Di samping itu, ibu cukup responsif terhadap gestur yang ditunjukkan dan kebutuhan anak. Meski tidak terlibat langsung dalam sesi intervensi di setting klinik, ayah beberapa kali bertanya mengenai program intervensi yang dijalankan serta perkembangan anak pada beberapa sesi.

Faktor pendukung kedua adalah penerapan prinsip DIR/Floortime di luar sesi intervensi yang dilakukan oleh ibu di lingkungan rumah. Peran aktif dan sikap responsif ibu tidak hanya ditunjukkan pada sesi intervensi di lingkungan klinik, tetapi juga diterapkan di lingkungan rumah. Hal tersebut sejalan dengan pernyataan Nelson (2013) serta Siller dan Sigman (2002) bahwa peran aktif ibu berdampak positif terhadap perkembangan anak dengan ASD, terutama pada kemampuan komunikasi. Faktor yang menghambat keberhasilan program adalah kondisi kesehatan anak dan ibu yang membuat pelaksanaan sesi harus diundur lama. Kondisi ibu yang sedang tidak prima juga berdampak pada kemampuan ibu untuk engage ke dalam permainan karena ibu kurang dapat mengikuti pergerakan anak selama bermain dan cenderung memanggil anak. Hal tersebut berdampak pada menurunnya kuantitas open dan jumlah $\mathrm{CoC}$ selama sesi.

Kelebihan dalam penelitian ini adalah menggunakan multiple baseline across situations untuk membandingkan efek intervensi pada kemampuan komunikasi dua arah anak pada dua setting, yaitu setting free dan semi-structured play. Data yang diperoleh pun dinilai reliabel karena peneliti melakukan interrater reliability pada pengukuran CoC dan FEAS. Di sisi lain, terdapat keterbatasan dalam penelitian ini. Pertama, uji validitas alat ukur $\mathrm{CoC}$ dan FEAS yang digunakan dalam penelitian ini hanya dilakukan dengan melakukan validitas konten. Kedua, penerapan DIR/Floortime dalam intervensi ini tidak melibatkan ahli multidisiplin.

\section{SIMPULAN}

Berdasarkan hasil penelitian, peneliti memperoleh beberapa kesimpulan. Pertama, terdapat peningkatan kuan- 
titas open anak pada setting free dan semi-structured play. Hal itu menandakan bahwa setelah diberikan intervensi DIR/Floortime, kemampuan anak dalam melakukan inisiasi komunikasi meningkat baik pada setting free play maupun semi-structured play. Kedua, terdapat peningkatan jumlah CoC pada setting free dan semi-structured play. Hal itu menandakan bahwa setelah diberikan intervensi DIR/Floortime, jumlah komunikasi dua arah yang anak lakukan bersama ibu meningkat pada setting free dan semi-structured play. Ketiga, terdapat peningkatan pada perkembangan functional emotional anak dan ibu pada kedua setting bermain setelah diberikan intervensi DIR/Floortime.

Berdasarkan keterbatasan yang terdapat pada penelitian ini, terdapat beberapa saran yang dapat dilakukan untuk penelitian selanjutnya. Pertama, penelitian selanjutnya dapat melakukan uji validitas konstruk pada lembar observasi circle of communication dan FEAS. Kedua, Penelitian selanjutnya tidak hanya menghitung jumlah inisiasi yang anak lakukan (open anak) dan juga jumlah CoC, tetapi juga menghitung close anak serta open dan close ibu agar dapat membandingkan jumlah inisiasi dan respon yang diberikan oleh anak dan ibu pada keseluruhan komunikasi dua arah yang terjalin. Selain itu, perhitungan pada setiap komponen CoC (open dan close anak, open dan close ibu, jumlah $\mathrm{CoC}$ ) dapat memberikan gambaran yang lebih terperinci mengenai pola interaksi antara anak dengan ibu.

Ketiga, pada penelitian ini, seluruh sesi dilaksanakan dengan urutan bermain pada setting free play dan dilanjutkan dengan setting semi-structured play. Pada penelitian selanjutnya, sesi-sesi awal dapat dilakukan dengan urutan yang sama. Apabila setelah beberapa sesi partisipan mulai terbiasa dengan penerapan prinsip DIR/Floortime, pelaksanaan sesi selanjutnya dapat diubah dengan bermain pada setting semi-structured play kemudian dilanjutkan pada setting free play. Keempat, penelitian selanjutnya dapat melibatkan ayah dan tidak hanya melibatkan ibu dalam pelaksanaan intervensi. Jumlah sesi intervensi pun dapat ditambahkan sesuai dengan kebutuhan anak dan target yang ingin dicapai.

\section{DAFTAR PUSTAKA}

American Psychiatric Association. (2013). Diagnostic and Statistical Manual of Mental Disorders, Fifth Edition. DSM-5. Washington: American Psychiatric Publishing.

Anastasi, A., Urbina, S. (1997). Psychologycal Testing. New Jersey: Simon Publising.

Baio, J., Wiggins, L., Christensen, D.L., Maenner, M.J., Daniels, J., Warren, Z., Kurzius-Spencer, M., Za- horodny, W., Robinson, C., Rosenberg, White, T., Durkin, M.S., Imm, P., Nikolaou, L., Yeargin-Allsopp, M., Lee, L.C., Harrington, R., Lopez, M., Fitzgerald, R.T., Hewitt, A., Pettygrove, S., Constantio, J.N., Vehorn, A., Shenouda, J., HallLande J., Van, K., Braun, N., Dowling, N.F. (2018). Prevalence of Autism Spectrum Disorder Among Children Ages 8 Years - Autism and Developmental Disabilities Monitoring Network, 11 Seites, United States, 2014. Surveillance Summaries, 67(6), 1 - 23.

Boediman, L.M., \& Mardian, M.G. (2017). Using a developmental-relationship-based approach for improving the joint attention of a child with autism: A single-case design. Advances in Social Science, Education, and Humanities Research, $135,72-81$.

Bourgeron, T. (2015). From the genetic architecture to synaptic plasticity in autism spectrum disorder. Nature Reviews Neuroscience, 16, 551-563.

Creswell, J.W. (2012). Educational Research, 4th ed.: Planning, Conductiong, and Evaluating Quantitative and Qualitative Research. Boston: Pearson.

Dionne, M., \& Martini, R. (2011). Floor time play with a child with autism: A single-subject study. Canadian Journal of Occupational Therapy, 78, 196203.

Gravetter, F.J., \& Forzano, L.B. (2012). Research Methods for the Behavioral Sciences. Belmont: Wadsworth.

Greenspan, S.I., \& Salmon, J. (1995). The Challenging Child: Understanding, Raising, and Enjoying the Five "Difficult" Types of Children. Massachussets: Addison-Wesley Publishing Company.

Greenspan, S.I., DeGangi, G., Wieder, S. (2001). The Functional Emotional Assessment Scale (FEAS) for Infancy and Early Childhood: Clinical and Research Applications. Bethesda: Interdiciplinary Council on Developmental and Learning Disorder (ICDL).

Greenspan, S.I., \& Wieder, S. (1998). The child with special needs: Encouraging intellectual and emotional growth. Massachusetts: Perseus Books.

Greenspan, S.I., \& Wieder, S. (2006). Infant and Early Childhood Mental Health: A Comprehensive Developmental Approach to Assessment and Intervention. Washington: American Psychiatric Publishing, Inc. 
Greenspan, S.I., \& Wieder, S. (2009). Engaging Autism: Using the Floortime Approach to Help Children Relate, Communicate, and Think. Philadelphia: Da Capo Press.

Hallgren, K. A. (2012). Computing inter-rater reliability for observational data: An overview and tutorial. Tutorials in Quantitative Methods for Psychology, 8(1), 23- 34 .

Hedenbro, M., \& Tjus, T. (2007). A case study of parent-child interactions odf a child with autistic spectrum siorder (3 - 48 months) and comparison with typically-developing peers.

Hess, E.B. (2013). DIR/Floortime: Evidence based practice towards the treatment of autism and sensory processing disorder in children and adolescents. International Journal of Child Health and Human Development, 6(3), $1-11$.

Hess, E.B. (2016). DIR/Floortime: A development/ relatuonal play therapy approach toward the treatment of children with developmeny delays, including autism spectrum disorder (ASD) and sensory processing challenges. Dalam O'Sonnor, K., Schaefer, C., Braverment, L.D. (2016). Handbook of Play Therapy (2nd ed.).

Interdisciplinary Council on Developmental and Learning Disorders. (2002). Clinical Practice Guidelines: Redefining the Standards of Care for Infants, Children, and Families with Special Needs. Bethesda: The Interdisciplinary Council on Developmental and Learning Disorders.

ICDL-DMIC. (2005). The Interdisciplinary Council on Development and Learning Disorder - Diagnostic Manual for Infancy and Early Childhood. Maryland: The Interdisciplinary Council on Developmental and Learning Disorders.

Kaplan, R.M., \& Saccuzzo, D.P. (2005). Psychological Testing: Principles, Applications, and Issues. Belmont: Wadsworth.

Kasari, C., Glusrud, A., Freeman, S., Paparella, T, Hellemann, G (2012). Longitudinal follow up of children with autism receiving targeted interventions on joiny attention and play $\mathrm{RH}=$ Targeten interventions on joint attention and play. Journal of the American Academy of Child \& Adolescent Psychiatry, 51(5), 487 - 495.

Koo, T. K., \& Li, M. Y. (2016). A guideline of selecting and reporting intraclass correlation coefficients for reliability research. Journal of Chiropractic Medicine, 15(2016), 155-163.

Lal, R., \& Chhabria R. (2013). Early Intervention of Autism: A Case for Floor Time Approach. Recent Advances in Autism Spectrum Disorders, 1(29), $691-715$.

Lindgren, S., \& Doobay, A. (2011). Evidence-Based Intervention for Autism Spectrum Disorder. Iowa: The Center for Disabilities and Development of University of Iowa Children's Hospital.

Marco, E.J., Hinkley, L.B.N., Hill, S.S., Nagarajan, S.S. (2011). Sensory processing in autism: A review of neurophysiologic Findings. Pediatric research, $5(69) .48-54$.

Mercer, J. (2017). Examining DIR/Floortime as a treatment for children with autism spectrum disorder: A review of research and theory. Research on Social Work Practice, 1(11), doi: $10.1177 / 1049731515583062$

Miles, J.H. (2011) Autism spectrum disorders, a genetics review. Genetics in Medicine, 13, 278-294.

Miltenberger, R.C. (2012). Behavior Modification: Principles and Procedeures. Belmont: Wadsworth.

Morgan, L.J., Rubin, E., Coleman, J.J., Frymark, T., Wang, B.P., Cannon, L.J. (2014). Impact of social communication interventions on infants and toddlers with or at-risk for autism: A systematic review. Focus on Autism and Other Developmental Disabilities, 29(4), 246 - 256.

Nelson, K.A. (2013). Parental Involvement in Early Intervention Programs for Children with Autism. Diakses dari the St. Catherine University repository website: https://sophia.stkate.edu/msw_papers/239.

Pajareya, K., \& Nopmaneejumruslers, K. (2011). A pilot randomized controlled trial of DIR/Floortime parent training intervention for pre-school children with autistic spectrum disorders. Autism, 15(2), $563-577$.

Paul, R. (2008). Interventions to improve communication in autism. Child and Adolescent Psychiatric Clinics of North America, 17(2008), 835 - 856.

Phandinata, S.R., Atmodiwirjo, E.T., \& Basaria, D. (2017). Developmental individula-differences relationship-based (DIR) Floortime dalam meningkatkan komunikasi dua arah pada kasus autism spectrum disorder (ASD). Jurnal Psibern- 
erika, 10(2), $103-113$.

Robert, C., Pasquier, L., Cohen, D., Fradin, M., Canitano, R., Damaj, L., Odent, S., Tordjman, S. (2017). Role of genetics in the etiology of Autistic Spectrum Disorder: Towards a Hierarchical Diagnostic Strategy. International Journal of Molecular Sciences, 18(618), doi:10.3390/ijms18030618.

Robinsin, L.E., Palmer, K.K., Bub, K.L. (2016). Effect of the Children's Health Activity Motor Program on Motor Skills and Sel-Regulation in Head Start Preschoolers: An Efficacy Trial. Frontier in Public Health, 4, doi:10.2289/fpubh.2016.00173.

Santoso, S. (2019). Penerapan Pendekatan Floortime untuk Meningkatkan Komunikasi Timbal Balik Pada Remaja dengan Autism Spectrum Disorder (Tesis tidak dipublikasikan). Universitas Indonesia, Depok, Indonesia.

Shire, S. Y., Gulsrud, A., \& Kasari, C. (2016). Increasing Responsive Parent - Child Interactions and Joint Engagement: Comparing the Influence of Parent-Mediated Intervention and Parent Psychoeducation. Journal of Autism and Developmental Disorders, 46(5), 1737-1747.

Siller, M., \& Sigman, M. (2002). The behaviors of parents of children with autism predict the subsequent development of their children's communication. Journal of Autism and Developmental Disorders, 32, 77-90.

Tordjman, S., Somogyi, E., Coulon, N., Kermarrec, S., Cohen, D., Bronsard, G., Bonnot, O., Weis-
mann-Arcache, C., Botbol, M., Lauth, B., Ginchat, V., Roubertoux, P., Barburoth, M., Kovess, V., Geoffray, M.M., Xavier, J. (2014). Gene $\mathrm{X}$ environment interactions in autism spectrum disorders: role of epigenetic mechanism. Frontiers in Psychiatry, 5(53), doi: 10.3389/fpsyt.2014.00053.

Vernon, T.W., Koegel, R.L., Dauterman, H., Stolen, K. (2012). An early social engagement intervention for young children and their parents. Journal of Autism and Developmental Disorder, 42(12), $2702-2717$.

Virues-Ortega, J., \& Rodriguez, V. (2013). Prediction of treatment outcomes and longitudinal analysis in children with autism undergoing intensive behavioral intervention. International Journal of Clinical and Health Psychology, 13(2), 91 - 100.

Wieder, S. \& Greenspan, S.I. (2003). Climbing the symbolic ladder in the DIR model through floortime/ interactive play. Autistic Society, 7(4), 425 - 435.

Yudhiatmoko, A. (2014). Uji validasi dan reliabilitas instrumen profil sensori singkat untuk anak usia 3 10 tahun (Master's thesis). Diakses dari http://lib. ui.ac.id/file?file=digital/20367174-SP-Allan $\% 20$ Yudhiatmoko.pdf

Yoder, P., \& Stone, W.L. (2006). Randomized comparison of two communication interventions for preschoolers with autism spectrum disorders. Journal of consulting and clinical psychology, 74(3), $426-435$. 